\title{
PRELIMINARY INVESTIGATION OF A COLOURING MATTER EXTRACT FROM SORGHUM BICOLOR SHEATHS AND ITS APPLICATION TO TEXTILE SUBTRATES
}

\author{
*Gumel, M.S. ${ }^{1}$ and Ali, . $^{2}$ \\ ${ }^{1}$ Department of Pure and Industrial Chemistry, Bayero University Kano. \\ ${ }^{2}$ Department of Science Laboratory Technology, Jigawa state Polytechnic. \\ *Correspondence author: sani_gumel@yahoo.com
}

\begin{abstract}
The colouring matter from the sheath of sorghum bicolor was extracted using ethanol, acetone, water and petroleum ether, respectively. Ethanol exhibited higher extract percentage yield compared to the other solvents with petroleum ether giving the least. The chromatographic analysis indicates that the extract contains only one component which maximally absorbs at 1.78 and 1.58 in ethanol and water, respectively. The extracted colouring matter was applied to cotton, nylon, and wool fabrics with better results obtained on nylon fabric. The use of Potassium Chromate as a mordant however, generally improves the colour yield on the nylon and with improved wash fastness properties in all the fabrics used.

Keywords: Extraction, Investigation, colouring matter, Sorghum bicolor
\end{abstract}

INTRODUCTION

The colouring of textiles, leather and other natural products is receiving increasing attention. Recently, there has been a much greater interest and researches in producing, testing, and applying natural dyes and pigments (Hill, 1997). What attracts people to textiles coloured with natural dyes may be one or combination of factors, including a preference for naturalness, environmental friendliness, and harmonizing natural shades (Hill, 1997).Natural dyes, when used by themselves have some limitations of fastness and brilliancy of shade. However, when used along with metallic mordant they produce bright and fast colours (Chakrabarti andVignesh, 2011)

Sorghum bicolor is a specie of Sorghum with strong stem ranging from $1-4 \mathrm{~m}$; the stem can be juicy or dry, sweet or bitter. Leaves are arranged alternatively and have prominent mid veins and parallel lateral veins. Long overlapping sheaths are attached at the node (Umar, 2009). Many edible and non-edible sorghum cultivars are grown for the red dye present in the leaf sheath and sometimes also in adjacent stem parts. In Africa this colouring matter is used particularly for goat-skin leather in Nigeria, but also for mats, textiles, trips of palm leaves and grasses used in basketry and weaving, ornamental calabashes and wool in Sudan (Balole and Legwaila, 2005)

The use of Sorghum bicolor leaf sheath as a remedy against anaemia (reduction of red blood cells or its function) by traditional medicine healers is common in Nigeria particularly within the local people of the Yoruba and Hausa tribes (Akande etal, 2010). Malted Sorghum bicolor grain is higher in protein and lower in fat content than Corn and this is partly responsible for its medicinal potential (haemopoietic ability) (Makokha et al., 2002).
The extraction and application of colouring matter from the sheath of Sorghum bicolor will, therefore, be of great contribution to the exploitation of natural dyes and their applications. The research work is aimed to contribute towards the use of natural dyes as a substitute to synthetic ones in the colouration industries.

\section{MATERIALS AND METHODS}

The materials and reagents used are ethanol, acetone, distilled water, petroleum ether, butanol, acetic acid, potassium chromate, detergent, soap, and other common laboratory glasswares. The reagents are of Analytical grade and were used with out further purification. The dried sheaths of Sorghum bicolor were obtained from Kurmi market, Kano, Nigeria. Glasswares used were pyrex type and were washed with detergent, rinsed with distilled water and dried before use. $\mathrm{pH}$ meter used model xJenway3320 and UV/visible Spectrophotometer model Pye Unicam UVVisible Spectrophotometer.

\section{Extraction of Colouring Matter}

Fifty gram $(50 \mathrm{~g})$ of finely ground sheaths of Sorghum bicolor was percolated in $500 \mathrm{~cm}^{3}$ of ethanol, distilled water, acetone, and petroleum ether, separately, for the period of 2 weeks. It was then filtered and concentrated using rotary evaporator. The extract was allowed to dry at room temperature and then weighed.

\section{pH Measurement}

One gram $(1 \mathrm{~g})$ of each extract was weighed and dissolved in $20 \mathrm{~cm}^{3}$ of water and ethanol, respectively, and the $\mathrm{pH}$ was determined using $\mathrm{pH}$ meter model xJenway3320. 


\section{Paper Chromatographic Analysis}

Two solvent mixtures were used; Butanol, acetic acid, and water (40:10:50) and water, ethanol, ammonium hydroxide, and pentanol (20:30:20:30). This is for effective and wholesome extraction (Vogel, 1956).

The solvent mixtures were placed in different solvent tanks with cover. The samples were spotted on whatman Chromatographic paper and allowed to dry.

The papers were vertically fixed at the cover of the solvent tanks and the tanks were covered. Then chromatograms were run for 40minutes, after which they were removed and the solvent front was marked. The chromatograms were developed in iodine crystals for 10minutes and the solvent fronts were also marked (Filffield and kealy, 1990).

\section{UV/Visible Absorption Measurement}

UV spectrophotometer was used to record the absorption of the dye extracts after making a concentration each of $1 \mathrm{~g}$ in $20 \mathrm{~cm}^{3}$ of water and ethanol respectively (Burgees and Knowles, 1981).

\section{Dyeing}

\section{Dyeing with out Mordant}

One gram $(1 \mathrm{~g})$ of each extract was dissolved in $40 \mathrm{~cm}^{3}$ of ethanol and $40 \mathrm{~cm}^{3}$ of water, respectively and the temperature rise to $70^{\circ} \mathrm{C}$.

One gram $(1 \mathrm{~g})$ cotton, were immersed in the warmed dye solutions and dyed at boil for 1 hour. The samples were finally rinsed and dried. (Nkeonye, 1993) The same procedure was used on wool and nylon fabrics.

\section{Dyeing with Mordant}

The textile fabrics (cotton, wool and nylon) were first treated with $0.4 \%$ solution of Potassium Chromate (mordant) at boil for one hour (Gill, 1993). The mordanted fabrics were then dyed, rinsed and dried as above.

\section{Fastness Properties Test}

Both the mordanted and unmordanted dyed fabric samples were each assessed for their wash and light fastness properties in accordance with the standard procedures (Abrahart, 1977)

\section{Wash Fastness Test}

The dyed fabrics were each washed with both soap and detergent, respectively. $5 \mathrm{~g}$ of detergent and soap was dissolve in 1 litre of warm water separately and used for the wash test. The washed samples were rinse, dried, and assessed with grey scale accordingly.

\section{Light Fastness Test}

The dyed fabric samples were tested for light fastness along with eight blue wool standards on light fastness tester for 120 hours (5days) and assessed accordingly.

\section{RESULTS AND DISCUSSION}

The percentage yield was generally found to be low with ethanol extract having the highest and petroleum ether having the lowest. This indicates that, ethanol is the best solvent for the extraction. The lowest value shown by the petroleum ether may be attributed to the fact that it dissolves very little of the colouring matter. The $\mathrm{pH}$ values were found to be slightly acidic. Water and Ethanol being neutral solvents the acidity may be due to the extracted colouring matter extract (Martins and Ojukwu, 1999).

The UV-visible absorption of water and ethanol extracts were found to be 1.78 and 1.58 respectively. The variation in the absorbance value may be attributed to the solvent shift due hypsochromic or hypochromic effect (Burgees and Knowles, 1981).

The RF values of the ethanol, Acetone, and petroleum ether were found to be $0.99,0.99$, and 0.97 respectively. The R.F values are relatively the same therefore, the paper chromatography indicates that the extracts contain only one component colouring matter (Pavia and Kris, 1990).

\section{Dyeing of some Textile Fabrics}

After the application of the dye to the fabrics redish brown hue obtained in each case. The use of Potassium Chromate as mordant, found to change the colour to dark brown with nylon fabric darker than the rest. This is due to the fact that mordant agents are capable of forming complexes with dyes thus, producing a more intense colour on the substrate (Gill, 1993). The percentage yields and $\mathrm{pH}$ of different extracts were determined as shown in the Table 1.

Table 1: Percentage yield of the Extraction

\begin{tabular}{lcl}
\hline Solvent & Percentage yield (\%) & pH Values \\
\hline Ethanol Extract & 29.54 & 6.95 \\
Acetone Extract & 10.86 & 6.59 \\
Distilled Water Extract & 6.40 & 6.20 \\
Petroleum Ether Extract & 1.56 & 6.00
\end{tabular}

\section{Wash and Light Fastness Property}

The results generally show that the fabrics dyed with mordant gave a better wash fastness property than the unmordant dyed fabrics. This is due to the formation of more complex structure of the dye with the mordant for more substantivity (Abrahart, 1977)

Samples washed with soap were found to have better fastness property, than those washed with detergent. This may be attributed to presences of some additives such as bleaching agent in the detergent (Gill, 1993). Cotton fabric exhibited a poor wash fastness property compared to wool and nylon. However, mordant dyed wool and nylon showed very good fastness to washing. This indicates that they both have good affinity to the mordant used (Gill, 1993).

The light fastness results were generally poor, but with the use of mordant the fastness improved. The dyed of nylon with mordant shows a better property than the rest. 
The wash and light fastness of the dyed fabrics of cotton, wool, and nylon was shown in Table 2 below:

Table 2: Wash fastness

\begin{tabular}{lccc}
\hline \multicolumn{4}{c}{ Washing Fastness } \\
\hline Dyed Samples & Detergent & Soap & Light fastness \\
\hline 1A & 1 & 1 & 2 \\
$1 B$ & 3 & 4 & 3 \\
2A & 1 & 1 & 2 \\
2B & 3 & 5 & 3 \\
3A & 1 & 1 & 2 \\
$3 B$ & 4 & 5 & 4 \\
\hline
\end{tabular}

Key: $1 A=$ Cotton fabric dyed without mordant, $1 B=$ Cotton fabric dyed with mordant, $2 A=$ Wool fabric dyed without mordant, $2 \mathrm{~B}=$ Wool fabric dyed with mordant, $3 \mathrm{~A}=$ Nylon fabric dyed without mordant, $3 \mathrm{~B}=$ Nylon fabric dyed with mordant

\section{CONCLUSION}

Ethanol was found to be the best solvent for the extraction of the dye from the sheaths of Sorghum bicolor. The colouring matter was substantive to cotton, wool, and nylon fabrics, with nylon better than the wool and cotton.

The Potassium Chromate mordant found to intensify the colour and improved the washing fastness of the dyed fabrics with very little or no effect to light fastness property.

\section{REFERENCES}

Abrahart E.N (1977) "Dyes and their Intermediates" $2^{\text {nd }}$ Edition, Edward Arnold Ltd, London. Pp 1,210 .

Akande, I.S. , Oseni, A.A. and Biobaku,O.A. (2010) "Effect of aqueous extract of Sorghum bicolor on hepatic, histological and haematological indices in rats" Journal of Cell and Animal Biology Vol. 4(9),Pp. 137-142.

Burgees C. and Knowles A. (1981) "Techniques in Visible and Ultraviolet Spectrometry vol.1: Standard in Absorption Spectrometry, UV Spectrometry group" $1^{\text {st }}$ Edition, Holt Rinehart and Winston, U.S.A. Pp1and 133.

Balole, T.V and Legwaila, G.M, (2005) "Sorghum bicolor (L.) Moench" (Internet) record from protabase. Jansen. P.C.M and Cardon D. (Editors).

http://database.prota.org/search.htm. $21^{\text {st }}$ March, 2012.

Chakrabarti R. and Vignesh A. (2011) "Natural Dyes: Application, Identification and Standardization" Article, www.fibre2fasion.com. $14^{\text {th }}$ March, 2012.

Doggett H. (1988) "Sorghum" $2^{\text {nd }}$ Edition, Lognman Scientist and Technical, U.K Pp1and 428.

Filffield F. and Kealy D.(1990) "Principles and Practice of Analytical Chemistry" $3^{\text {rd }}$ Edition, Blackie and Son Ltd. Glasgow and London. Pp 11.

Gill D. (1993) index "Greener Mordant for Natural colouration" Journal of the society of dyers and Colourist, Vol.109: 8-9.
Therefore, we recommend further investigations on the colouring matter such as dyeing with different mordant, and structural elucidation.

\section{Acknowledgement}

The authors acknowledge the Laboratory instruments support by the department of Pure and Industrial Chemistry, Bayero University Kano.

Hill D.J (1997) "Is there a Future for Natural Dyes" Rev. Prog. Colouration Vol. 27 Pp18-24.

Makokha A. O. Oniango R.K, Njoroge S.M, Kinyanjui P.K (2002) "Effect of malting on protein digestibility of some Sorghum (Sorghum bicolor) varieties grown in Kenya" Afri. J. Foods Nutr.Sci. , 2(2): 168-175.

Martins C.M.O and Ojukwu G.O. (1999) "Concise Organic Chemistry: Introduction to Organic Chemistry vol. $11^{\text {st }}$ Edition, Silver Bond Publications, and Nigeria. Pp208-209,212213.

Nkeonye P.O. (1993) "Introductory Textile for Home Economist Student of Art and Beginner generally" $1^{\text {st }}$ Edition, Asekome and Co. Publishers, Zaria. Pp 1, 8, 12, and 108.

Pavia L., and Kris E. (1990) "Introduction to Organic Laboratory Techniques." $3^{\text {rd }}$ Edition, Saunder College publishing U.S.A. Pp331.

Sarkar K.T. (1976) "Theory and Practice of Leather Manufacture" $2^{\text {nd }}$ Edition, Longman Publishers, India. Pp76.

Umar A. (2009) "Effect of Raw and Modified Sorghum Cellulose Fibre on the Mechanical Properties of Natural Rubber Composite" MSc. Dissertation. Dept. of Pure and Industrial Chemistry (B.U.K).

Vogel A. I (1956) "A Textbook of Practical Organic Chemistry including Qualitative Organic Analysis" $3^{\text {rd }}$ Edition, Longman Green and Co. Ltd. Great Britain. Pp44-151. 